Title: Embryo gene expression in pig pregnancy

3 Author: Llobat Lola*

4

5 Affiliation: Grupo Fisiopatología de la Reproducción. Departamento Producción y Sanidad Animal, Salud Pública y

6 Ciencia y Tecnología de los Alimentos. Facultad de Veterinaria. Universidad Cardenal Herrera-CEU, CEU Universities.

$7 \quad$ Valencia. Spain

8

9 *Corresponding Author: Llobat L, ${ }^{1}$ Grupo Fisiopatología de la Reproducción. Departamento Producción y Sanidad 10 Animal, Salud Pública y Ciencia y Tecnología de los Alimentos. Facultad de Veterinaria. Universidad Cardenal Herrera11 CEU, CEU Universities. Valencia. Spain

13 Summary: Pregnancy is a complex process which significant changes occurring continually in both the corpora lutea and in the endometrium of the females and varies depending on the embryonic, pre-implantation, or foetal stages. In the embryonic stages, the majority of genes expressed in the pig embryo correspond to the loss of cellular pluripotency. In contrast, the implantation consists of three phases: elongation of the conceptus, adhesion, and union of the embryo to the endometrial epithelium. During these phases, many factors are expressed, including growth factors, molecules that facilitate adhesion, and cytokines, among others. All these changes are ultimately regulated by different lipid and hormonal substances, specifically by progesterone, oestradiol, and prostaglandins, which regulate the expression of many proteins necessary for the development of the embryo, endometrial remodelling, and embryo-maternal communication. This paper is a review of primary gene regulatory mechanisms in pigs during different stages of implantation.

Keywords: gene expression, molecular mechanisms, reproduction 
Pluripotency transcription factors

The most critical transcription factors related to pluripotency in all mammals species are the Oct4 transcription factor (belonging to the POU gene family), Nanog and SOX2 transcription factor, expressed predominantly in pluripotent cells (Boyer et al., 2006). Among these, previous studies have shown Oct4 is required to cell differentiation processes in different mammalian species, such as human, mice, rabbit and pig, and is expressed earlier, and required for embryonic cells differentiation (Assadollahi et al., 2019; De Los Angeles et al., 2019; Dode et al., 2006; Fair et al., 2004; Llobat et al., 2012; Shen et al., 2019). Oct4 transcription factor binds to DNA during embryonic development and acts as a gene activator or repressor during cell differentiation and early embryonic development (Smith et al., 2007). In pigs, Oct4 expression is present in trophoblast and inner cell mass (ICM) (Hall et al., 2009; Vejlsted et al., 2006). Both Nanog and SOX2 are expressed in swine ICM, and are also detected on day 8.5 in the early epiblast, whereas Oct4 seems to start on day 10 (du Puy et al., 2011; Hall et al., 2010; Shen et al., 2019; Yoon et al., 2019)

However, in porcine and mouse ICM, other transcription factors related to pluripotency such as GATA6 have been detected (Kuijk et al., 2008; Meng et al., 2018; Schrode et al., 2014).. Nevertheless, Hall (2012) indicate a possible entry of the embryo at rest due to the lack of genes expressed in the ICM, while during the same stage, the epiblast expresses several genes, such as $\operatorname{SMAD}(1,2,3,4$ and 5) or $B M P 4$, demonstrates higher pluripotent activity in porcine epiblast than in ICM, which exhibits a very premature pluripotency (Hall et al., 2010; Hall \& Hyttel, 2014; Kuijk et al., 2008; Wolf et al., 2011). Furthermore, recent studies in cloned embryos showed the dependence of pluripotency-related and apoptosis gene expression on epigenetic transformations (Samiec et al., 2019). The single-cell expression analysis technique pluripotency-related genes in pig embryos, such as paired box 6 (PAXØ) and aquaporin $3(A Q P 3)$, and, in late blastocysts, clathrin adaptor protein $(D A B 2)$, platelet-derived growth factor receptor alpha (PDGFRA), fibronectin 1 (FN1), hepatocyte nuclear factor 4 alpha $(H N F 4 A)$, goosecoid homeobox (GSC), nuclear receptor subfamily 5 group A member 2 (NR5A2) and lysine acetyltransferase 6A (KAT6A) (Wei et al., 2018). However, the underlying factors involved in pluripotency and its regulation require further study.

\section{Vascular endothelial and transforming growth factors}


61 The adhesion process can be affected by growth factors that regulate vascularisation and cell motility. One such factor

62 the vascular endothelial growth factor $(V E G F)$, is associated with de novo vascularisation during processes such as

63 implantation, embryogenesis, menstrual cycle, development of luteal bodies, development of ovarian follicles and tumorigenesis (Ferrara et al., 1998; Valdés et al., 2008). In pigs, VEGF expression has recently been associated with foetal weights at 80 and 105 days of pregnancy (Guimarães et al., 2017). Moreover, studies in vitro shows an increase development of porcine embryos $V E G F$ dependent, suggesting $V E G F$ functions related not only to vascularization, but also to development and growth (Biswas et al., 2018).

68

Transforming growth factor superfamily $(T G F)$ is another group of transcription factors present in embryos of different species both before and during implantation. The $T G F-\beta$ regulates blastocyst differentiation and maturation events, including modulating the interactions between the uterus and embryo during implantation (Paria and Dey, 1990; Pauken and Capco, 1999). In pigs, the expression of integrin-mediated $T G F-\beta$ increases at the time of embryonic elongation and pre-implantation. This increase is related to several functions of $T G F-\beta$ in the maternal-embryonic interface, such as communication between the endometrium and conceptus (Jaeger et al., 2005; Li et al., 2019). Furthermore, recent studies have shown that GFD 8 (member of $T G F-\beta$ ) is involved in the expression of ICM marker $S O X 2$ during embryo in vitro development, indicating their role in preimplantation embryonic development (Yoon et al., 2019). Other growth factors, such fibroblast growth factor $2(F G F 2)$ and angiopoietins $(A N G P T S)$, has been related to vascularization during peri-implantation process, since it has recently been shown that prostaglandin increases the expression of $V E G F$ in trophoblast and FGF and ANGPTs in swine endometrium on days 15 and 20 (Kaczynski et al., 2019). These results suggest an important function of different growth factors mediated by prostaglandins in embryo development and creation of new blood vessels between endometrium and trophoblast in pigs.

\section{Family of Integrins}

Integrins are adhesion molecules involved in the maternal-embryonic interaction in different species. Pigs show increased expression of different integrin subunits in the endometrium on day 18 of pregnancy $(\alpha V \beta 3)$. However, integrin expression decreases on day 25 before implantation, which indicates a critical role for integrins during elongation and implantation stages (Lin et al., 2007). Among the group of integrins and their subunits, osteopontin (SSP1) is a phosphoprotein secreted by the matrix that binds integrin heterodimers $\alpha V$ and $\beta 6$ subunits and promotes the migration and binding of the trophectoderm to the endometrium (Erikson et al., 2009). SSP1 is involved in the 
regulation of signalling events related to adhesion, including invasion by the trophoblast and its migration (Johnson et al., 2003). In pigs, it was shown to contain an Arg-Gly-Asp (RGD) peptide sequence that joins the surface of the endometrium with the trophectoderm. In vitro studies showed that this peptide sequence is essential for both the elongation of the blastocyst and later stages of pregnancy, since it activates the ion transporters, thereby increasing nutrient transport (Laughlin et al., 2017). Furthermore, the mechanical forces from the union of the conceptus to the endometrium appear to be generated from the focal adhesions created during implantation and formed by SSPI and the $\alpha V$ subunit of the integrin. These focal adhesions are lost as placentation proceeds (Frank et al., 2017). The SSP1 protein present on the entire apical surface of the uterine cells and trophectoderm Nevertheless its expression is limited to the endometrium. Endometrial expression begins on day 11 and is induced by oestradiol to regulate maternal embryonic recognition (Burghardt et al., 2002; Johnson et al., 2003). Besides, increased expression of SSP1 in the porcine endometrium has been observed between days 25-30, and remains until day 85 , indicating the role of SSP1 not only in implantation, but also in later stages of pregnancy (Garlow et al., 2002). In pigs, the placenta is epitheliochorial, so that the placental barrier includes both the trophectoderm and the uterine epithelium (Wildman et al., 2006). Therefore, the factors that regulate or are related to the process of implantation are of great importance in the placentation. Recent studies showed relationship between foetal size and integrin expression, since regulate adhesion and foeto-maternal interface by interacting with SSP1 (Stenhouse et al., 2019). Concretely, SSP1 has a fundamental role, primarily in the non-invasive epitheliochorial placentation, and similar relates to processes that are occurring in pigs (Garlow et al., 2002; Rashev et al., 2005).

\section{Cytokines}

Cytokines are a group of proteins and glycoproteins (interleukins $(I L)$, tumour necrosis factors $(T N F)$, interferons (IFN), colony-stimulating factors ( $C S F s)$, and chemokines) produced by different cell types that act primarily as regulators of immune and inflammatory responses and are essential for maternal-embryonic recognition (Sharkey, 1998). Aproximately at day 12, pig embryo secretes $\operatorname{IFNs}(\gamma$ and $\delta$ ), and $I L$ (1B and 6) (Bazer, 2013). Specifically, the expression of interleukin $1 \beta, I L 1 B 2$ increases in the pig embryo around day 14 , indicating cytokine requirement for conceptus elongation and attachment to the uterine wall (Whyte et al., 2018). Other interleukins, such as $I L-2$ or $I L-4$, are produced by the foetal and maternal placentas from day-30, suggesting their role in maternal-foetal recognition (Vélez et al., 2019). Other important cytokines for successful pregnancy are interferons (IFN), which are classified into two families, type I and II interferons. The type II interferon family is composed of a single known gene, whose product 
is $\gamma$ interferon (De Maeyer and De Maeyer-Guignard, 1992), the primary product of T cells, and is found in different placental cell types, and human embryonic membrane and porcine trophoblast cells (Bazer et al., 1997). The other group of interferons, type I, is composed of different subtypes with similar biological properties, and interaction with the same receptor. This group includes interferons $\alpha, \beta, \delta, \omega$ and interferon $\tau$. Each subtype is different from each other in their amino acid sequence and serological properties, although all are involved in maternal-embryonic recognition (Aboagye-Mathiesen et al., 1995; Charlier et al., 1993; Charpigny et al., 1988; Cross and Roberts, 1989; Fung et al., 2004; Godornes et al., 2007; Imakawa et al., 1987; Kawasaki et al., 1992; Li et al., 2007; Muscettola et al., 2003). During pregnancy in pigs, interferons exert both paracrine and autocrine effects; however, the effects in the uterus are not well understood, although expression of interferon $\gamma$ type 2 has been observed in the trophectoderm cells (Lefèvre et al., 1998). In addition, the conceptus also expresses interferons, specifically $\gamma$ and $\delta$ interferons between days 12-20 of gestation (Cencic et al., 2003; Cencic and La Bonnardière, 2002; Joyce et al., 2007a, 2007b). The expression of interferon-stimulated genes (ISG), including $M x, I S G 15 / 17, I R F 1$, STAT1, and STAT2, is limited to specific uterine cells in pigs between days 14-18 of pregnancy (Hicks et al., 2003; Joyce et al., 2007a). The induction of ISG expression occurs, not only in pigs, but also in other mammalian species such as sheep, cows, mice, rat, primates, and humans, suggesting that the induction of $I F N$ promotes the gene expression in the uterine epithelium to facilitate implantation, placentation, and foetal development (Bazer et al., 2011). Recently, it has been shown that the IFN- $\gamma$ in the porcine trophoblast influences the expression of specific chemokines (CCL2, CCL5, CCL11, and CXCL12) required for endometrial communication with the trophoblast or recruitment of immune cells and establishment of an immunotolerant environment (CXCL9, CXCL10) for the embryo (Złotkowska and Andronowska, 2019).

\section{Insulin-like growth factors}

Insulin-like growth factors $(I G F s)$ are polypeptides with insulin-like sequences with mitogenic properties, for inducing proliferation and growth of somatic cells (Rinderknecht and Humbel, 1978). IGFs are also required for the regulation of amino acid and glucose transport in the placenta (Ashton and Spencer, 1983; Kniss et al., 1994). Type I receptor (IGF$I R)$ is a transmembrane tetrameric glycoprotein that resembles the insulin receptor and has a high affinity for both $I G F-I$ and $I G F-I I$ (Germain-Lee et al., 1992; Ullrich et al., 1986). In contrast, the type II receptor (IGF-IIR) is a single chain polypeptide with a high affinity for $I G F-I I$ and is unable to bind $I G F-I$ or insulin (Liu et al., 1993). IGF deficiencies exhibit distinct functional differences, and studies with IGF-IIR knock-out mice showed excessive placental and foetal growth (Kitamura et al., 2003). Studies in humans showed that mutations in the IGF-IR gene resulted in reduced 
functionality associated with low pre- and post-natal growth, or that excessive foetal growth occurs when $I G F-I I$ is overexpressed (Abuzzahab et al., 2003; Lau et al., 1994; Murrell et al., 2004; Wang et al., 2017). These results demonstrate that IGFs, together with their receptors, have an important role in the regulation of foetal and placental growth in most species (Wilson et al., 1982). Also, Fant and colleagues (1986) showed that the placenta produces both $I G F-I$ and $I G F-I I$, which act as local growth regulators in human. Specifically, $I G F-I I$ is expressed predominantly in the placenta, with both paracrine and autocrine functions, which are especially important during implantation and trophoblastic invasion (Giudice, 1997; Hamilton et al., 1997). However, the IGFs are not only related to the foetal and placental growth but also regulate different signalling cascades to promote both cell proliferation and differentiation (Clemmons \& Maile, 2005; Kitamura et al., 2003). Studies with preimplantation mouse embryos showed that decreased $I G F-I R$ induced apoptosis through a cascade of signal transduction pathways and enhanced embryonic resorption (Chi et al., 2000). Similar studies demonstrated the relationship between IGFs and embryonic losses in rat, pig, or humans (Katagiri et al., 1997; Pinto et al., 2002; Sferruzzi-Perri et al., 2007, 2006). The final group in the $I G F$ family is the IGF-binding protein group (IGFBP), a large group in humans consisting of six different proteins (Denley et al., 2005). Of these, dephosphorylated $I G F B P-1$ is found in the serum of pregnant women (Westwood et al., 1994), while IGFBP3 is produced by the placenta and foetal membranes (Han, 1996; Rogers et al., 1996). IGFBP-1 is involved in the regulation of $I G F S$ by inhibiting their functions, such as cell proliferation and differentiation, and trophoblastic migration (Gleeson et al., 2001; Hamilton et al., 1997; Irving et al., 1995; Ritvos et al., 1988). In pigs, the expression of $I G F-I$ is explicitly observed in both the uterine lumen and glandular epithelium of pregnant pigs, while the $I G F-I R$ is expressed in endometrial cells and the embryo, indicating the presence of both paracrine and autocrine functions (Letcher et al., 1989).

\section{Conclusions}

During different pregnancy stages in pigs, several cellular and molecular mechanisms are activated, each involving different transcription factors, growth factors, cytokines and others, related to cell differentiation, implantation, placentation, vascularisation and maternal-embryonic recognition. Despite extensive knowledge of these factors, the interaction of these factors with each other and the metabolic pathways involved remain to be clarified. The use of new technologies, such as single-cell gene expression, could help reveal the genes involved and their interactions. However, many questions about these and other molecules, as well as the interactions between them, remain to be discovered. 
I am grateful for the support and guidance provided by Dr. Mariola Soler, Dr. Carlos Garcés and specially, Dr. Lorena

Mocé, vice-dean of Veterinary Medicine Faculty to Universidad Cardenal Herrera-CEU.

\section{Conflict of Interest Statement}

The author are not conflict of interest.

\section{Data Availability Statement}

191

Data sharing is not applicable to this article as no new data were created or analysed in this study.

\section{References}

195

Aboagye-Mathiesen, G., Tóth, F.D., Zdravkovic, M., Ebbesen, P., 1995. Human trophoblast interferons: production and possible roles in early pregnancy. Early Pregnancy 1, 41-53.

Abuzzahab, M.J., Schneider, A., Goddard, A., Grigorescu, F., Lautier, C., Keller, E., Kiess, W., Klammt, J., Kratzsch, J., Osgood, D., Pfäffle, R., Raile, K., Seidel, B., Smith, R.J., Chernausek, S.D., Intrauterine Growth Retardation (IUGR) Study Group, 2003. IGF-I receptor mutations resulting in intrauterine and postnatal growth retardation. N. Engl. J. Med. 349, 2211-2222. https://doi.org/10.1056/NEJMoa010107

Ashton, I.K., Spencer, E.M., 1983. Effect of partially purified human somatomedin on human fetal and postnatal cartilage in vitro. Early Hum. Dev. 8, 135-140. https://doi.org/10.1016/0378-3782(83)90069-5

Assadollahi, V., Hassanzadeh, K., Abdi, M., Alasvand, M., Nasseri, S., Fathi, F., 2019. Effect of embryo cryopreservation on derivation efficiency, pluripotency, and differentiation capacity of mouse embryonic stem cells. J. Cell. Physiol. 234, 21962-21972. https://doi.org/10.1002/jcp.28759

Bazer, F.W., 2013. Pregnancy recognition signaling mechanisms in ruminants and pigs. J Animal Sci Biotechnol 4, 23. https://doi.org/10.1186/2049-1891-4-23

Bazer, F.W., Spencer, T.E., Johnson, G.A., Burghardt, R.C., 2011. Uterine receptivity to implantation of blastocysts in mammals. Front Biosci (Schol Ed) 3, 745-767. 
Bazer, F.W., Spencer, T.E., Ott, T.L., 1997. Interferon tau: a novel pregnancy recognition signal. Am. J. Reprod. Immunol. 37, 412-420. https://doi.org/10.1111/j.1600-0897.1997.tb00253.x

Biswas, D., So, K.H., Hwang, S.U., Yoon, J.D., Kim, M., Kim, D.Y., Hyun, S.H., 2018. Embryotropic effects of vascular endothelial growth factor on porcine embryos produced by in vitro fertilization. Theriogenology 120 , 147-156. https://doi.org/10.1016/j.theriogenology.2018.07.024

Boyer, L.A., Mathur, D., Jaenisch, R., 2006. Molecular control of pluripotency. Curr. Opin. Genet. Dev. 16, $455-462$. https://doi.org/10.1016/j.gde.2006.08.009

Burghardt, R.C., Johnson, G.A., Jaeger, L.A., Ka, H., Garlow, J.E., Spencer, T.E., Bazer, F.W., 2002. Integrins and extracellular matrix proteins at the maternal-fetal interface in domestic animals. Cells Tissues Organs (Print) 172, 202-217. https://doi.org/10.1159/000066969

Cencic, A., Guillomot, M., Koren, S., La Bonnardière, C., 2003. Trophoblastic interferons: do they modulate uterine cellular markers at the time of conceptus attachment in the pig? Placenta 24, 862-869. https://doi.org/10.1016/s0143-4004(03)00135-8

Cencic, A., La Bonnardière, C., 2002. Trophoblastic interferon-gamma: current knowledge and possible role(s) in early pig pregnancy. Vet. Res. 33, 139-157. https://doi.org/10.1051/vetres:2002003

Charlier, M., L'Haridon, R., Boisnard, M., Martal, J., Gaye, P., 1993. Cloning and structural analysis of four genes encoding interferon-omega in rabbit. J. Interferon Res. 13, 313-322. https://doi.org/10.1089/jir.1993.13.313

Charpigny, G., Reinaud, P., Huet, J.C., Guillomot, M., Charlier, M., Pernollet, J.C., Martal, J., 1988. High homology between a trophoblastic protein (trophoblastin) isolated from ovine embryo and alpha-interferons. FEBS Lett. 228, 12-16. https://doi.org/10.1016/0014-5793(88)80574-x

Chi, M.M., Schlein, A.L., Moley, K.H., 2000. High insulin-like growth factor 1 (IGF-1) and insulin concentrations trigger apoptosis in the mouse blastocyst via down-regulation of the IGF-1 receptor. Endocrinology 141, 47844792. https://doi.org/10.1210/endo.141.12.7816

Clemmons, D.R., Maile, L.A., 2005. Interaction between insulin-like growth factor-I receptor and alphaVbeta3 integrin linked signaling pathways: cellular responses to changes in multiple signaling inputs. Mol. Endocrinol. 19, 111. https://doi.org/10.1210/me.2004-0376

Cross, J.C., Roberts, R.M., 1989. Porcine conceptuses secrete an interferon during the preattachment period of early pregnancy. Biol. Reprod. 40, 1109-1118. https://doi.org/10.1095/biolreprod40.5.1109

De Los Angeles, A., Sakurai, M., Wu, J., 2019. Embryonic Chimeras with Human Pluripotent Stem Cells. Methods Mol. Biol. 2005, 125-151. https://doi.org/10.1007/978-1-4939-9524-0_9 
De Maeyer, E., De Maeyer-Guignard, J., 1992. Interferon-gamma. Curr. Opin. Immunol. 4, 321-326. https://doi.org/10.1016/0952-7915(92)90083-q

Denley, A., Cosgrove, L.J., Booker, G.W., Wallace, J.C., Forbes, B.E., 2005. Molecular interactions of the IGF system. Cytokine Growth Factor Rev. 16, 421-439. https://doi.org/10.1016/j.cytogfr.2005.04.004

Dode, M.A.N., Dufort, I., Massicotte, L., Sirard, M.-A., 2006. Quantitative expression of candidate genes for developmental competence in bovine two-cell embryos. Mol. Reprod. Dev. 73, 288-297. https://doi.org/10.1002/mrd.20427

du Puy, L., Lopes, S.M.C. de S., Haagsman, H.P., Roelen, B.A.J., 2011. Analysis of co-expression of OCT4, NANOG and SOX2 in pluripotent cells of the porcine embryo, in vivo and in vitro. Theriogenology 75, 513-526. https://doi.org/10.1016/j.theriogenology.2010.09.019

Erikson, D.W., Burghardt, R.C., Bayless, K.J., Johnson, G.A., 2009. Secreted phosphoprotein 1 (SPP1, osteopontin) binds to integrin alpha $\mathrm{v}$ beta 6 on porcine trophectoderm cells and integrin alpha $\mathrm{v}$ beta 3 on uterine luminal epithelial cells, and promotes trophectoderm cell adhesion and migration. Biol. Reprod. 81, 814-825. https://doi.org/10.1095/biolreprod.109.078600

Fair, T., Murphy, M., Rizos, D., Moss, C., Martin, F., Boland, M.P., Lonergan, P., 2004. Analysis of differential maternal mRNA expression in developmentally competent and incompetent bovine two-cell embryos. Mol. Reprod. Dev. 67, 136-144. https://doi.org/10.1002/mrd.10385

Fant, M., Munro, H., Moses, A.C., 1986. An autocrine/paracrine role for insulin-like growth factors in the regulation of human placental growth. J. Clin. Endocrinol. Metab. 63, 499-505. https://doi.org/10.1210/jcem-63-2-499

Ferrara, N., Chen, H., Davis-Smyth, T., Gerber, H.P., Nguyen, T.N., Peers, D., Chisholm, V., Hillan, K.J., Schwall, R.H., 1998. Vascular endothelial growth factor is essential for corpus luteum angiogenesis. Nat. Med. 4, 336-340. https://doi.org/10.1038/nm0398-336

Frank, J.W., Seo, H., Burghardt, R.C., Bayless, K.J., Johnson, G.A., 2017. ITGAV (alpha v integrins) bind SPP1 (osteopontin) to support trophoblast cell adhesion. Reproduction 153, 695-706. https://doi.org/10.1530/REP17-0043

Fung, M.C., Sia, S.F., Leung, K.N., Mak, N.K., 2004. Detection of differential expression of mouse interferon-alpha subtypes by polymerase chain reaction using specific primers. J. Immunol. Methods 284, 177-186. https://doi.org/10.1016/j.jim.2003.10.012

Garlow, J.E., Ka, H., Johnson, G.A., Burghardt, R.C., Jaeger, L.A., Bazer, F.W., 2002. Analysis of osteopontin at the maternal-placental interface in pigs. Biol. Reprod. 66, 718-725. https://doi.org/10.1095/biolreprod66.3.718 
Germain-Lee, E.L., Janicot, M., Lammers, R., Ullrich, A., Casella, S.J., 1992. Expression of a type I insulin-like growth factor receptor with low affinity for insulin-like growth factor II. Biochem. J. 281 ( Pt 2), 413-417. https://doi.org/10.1042/bj2810413

Giudice, L.C., 1997. Multifaceted roles for IGFBP-1 in human endometrium during implantation and pregnancy. Ann. N. Y. Acad. Sci. 828, 146-156. https://doi.org/10.1111/j.1749-6632.1997.tb48533.x

Gleeson, L.M., Chakraborty, C., McKinnon, T., Lala, P.K., 2001. Insulin-like growth factor-binding protein 1 stimulates human trophoblast migration by signaling through alpha 5 beta 1 integrin via mitogen-activated protein Kinase pathway. J. Clin. Endocrinol. Metab. 86, 2484-2493. https://doi.org/10.1210/jcem.86.6.7532

Godornes, C., Leader, B.T., Molini, B.J., Centurion-Lara, A., Lukehart, S.A., 2007. Quantitation of rabbit cytokine mRNA by real-time RT-PCR. Cytokine 38, 1-7. https://doi.org/10.1016/j.cyto.2007.04.002

Guimarães, G.C., Alves, L.A., Betarelli, R.P., Guimarães, C.S.O., Helmo, F.R., Pereira Júnior, C.D., Corrêa, R.R.M., Zangeronimo, M.G., 2017. Expression of vascular endothelial growth factor (VEGF) and factor VIII in the gilt placenta and its relation to fetal development. Theriogenology 92, 63-68. https://doi.org/10.1016/j.theriogenology.2017.01.002

Hall, V.J., 2012. Early development of the porcine embryo: the importance of cell signalling in development of pluripotent cell lines. Reprod. Fertil. Dev. 25, 94-102. https://doi.org/10.1071/RD12264

Hall, V.J., Christensen, J., Gao, Y., Schmidt, M.H., Hyttel, P., 2009. Porcine pluripotency cell signaling develops from the inner cell mass to the epiblast during early development. Dev. Dyn. 238, 2014-2024. https://doi.org/10.1002/dvdy.22027

Hall, V.J., Hyttel, P., 2014. Breaking down pluripotency in the porcine embryo reveals both a premature and reticent stem cell state in the inner cell mass and unique expression profiles of the naive and primed stem cell states. Stem Cells Dev. 23, 2030-2045. https://doi.org/10.1089/scd.2013.0502

Hall, V.J., Jacobsen, J.V., Rasmussen, M.A., Hyttel, P., 2010. Ultrastructural and molecular distinctions between the porcine inner cell mass and epiblast reveal unique pluripotent cell states. Dev. Dyn. 239, 2911-2920. https://doi.org/10.1002/dvdy.22424

Hamilton, H.H., Lukefahr, S.D., McNitt, J.I., 1997. Maternal nest quality and its influence on litter survival and weaning performance in commercial rabbits. J. Anim. Sci. 75, 926-933. https://doi.org/10.2527/1997.754926x

Han, V.K., 1996. The ontogeny of growth hormone, insulin-like growth factors and sex steroids: molecular aspects. Horm. Res. 45, 61-66. https://doi.org/10.1159/000184761 
Hicks, B.A., Etter, S.J., Carnahan, K.G., Joyce, M.M., Assiri, A.A., Carling, S.J., Kodali, K., Johnson, G.A., Hansen, T.R., Mirando, M.A., Woods, G.L., Vanderwall, D.K., Ott, T.L., 2003. Expression of the uterine Mx protein in cyclic and pregnant cows, gilts, and mares. J. Anim. Sci. 81, 1552-1561.

https://doi.org/10.2527/2003.8161552x

Imakawa, K., Anthony, R.V., Kazemi, M., Marotti, K.R., Polites, H.G., Roberts, R.M., 1987. Interferon-like sequence of ovine trophoblast protein secreted by embryonic trophectoderm. Nature 330, 377-379. https://doi.org/10.1038/330377a0

Irving, J.A., Lysiak, J.J., Graham, C.H., Hearn, S., Han, V.K., Lala, P.K., 1995. Characteristics of trophoblast cells migrating from first trimester chorionic villus explants and propagated in culture. Placenta 16, 413-433. https://doi.org/10.1016/0143-4004(95)90100-0

Jaeger, L.A., Spiegel, A.K., Ing, N.H., Johnson, G.A., Bazer, F.W., Burghardt, R.C., 2005. Functional effects of transforming growth factor beta on adhesive properties of porcine trophectoderm. Endocrinology 146, 39333942. https://doi.org/10.1210/en.2005-0090

Johnson, G.A., Burghardt, R.C., Bazer, F.W., Spencer, T.E., 2003. Osteopontin: roles in implantation and placentation. Biol. Reprod. 69, 1458-1471. https://doi.org/10.1095/biolreprod.103.020651

Joyce, M.M., Burghardt, J.R., Burghardt, R.C., Hooper, R.N., Jaeger, L.A., Spencer, T.E., Bazer, F.W., Johnson, G.A., 2007a. Pig conceptuses increase uterine interferon-regulatory factor 1 (IRF1), but restrict expression to stroma through estrogen-induced IRF2 in luminal epithelium. Biol. Reprod. 77, 292-302. https://doi.org/10.1095/biolreprod.107.060939

Joyce, M.M., Burghardt, R.C., Geisert, R.D., Burghardt, J.R., Hooper, R.N., Ross, J.W., Ashworth, M.D., Johnson, G.A., 2007b. Pig conceptuses secrete estrogen and interferons to differentially regulate uterine STAT1 in a temporal and cell type-specific manner. Endocrinology 148, 4420-4431. https://doi.org/10.1210/en.2007-0505

Kaczynski, P., Goryszewska, E., Baryla, M., Waclawik, A., 2019. Prostaglandin F2 $\alpha$ stimulates angiogenesis at the embryo-maternal interface during early pregnancy in the pig. Theriogenology 142, 169-176. https://doi.org/10.1016/j.theriogenology.2019.09.046

Katagiri, S., Moon, Y.S., Yuen, B.H., 1997. A somatostatin analogue decreases embryonic loss following superovulation in rats by normalizing insulin-like growth factor-I action in the uterus. Hum. Reprod. 12, 671-676. https://doi.org/10.1093/humrep/12.4.671

Kawasaki, H., Moriyama, M., Nariuchi, H., 1992. Mechanism of augmentation of endotoxin fever by beta interferon in rabbits: possible participation of tumor necrosis factor (cachectin). Infect. Immun. 60, 933-936. 
Kitamura, T., Kahn, C.R., Accili, D., 2003. Insulin receptor knockout mice. Annu. Rev. Physiol. 65, $313-332$. https://doi.org/10.1146/annurev.physiol.65.092101.142540

Kniss, D.A., Shubert, P.J., Zimmerman, P.D., Landon, M.B., Gabbe, S.G., 1994. Insulinlike growth factors. Their regulation of glucose and amino acid transport in placental trophoblasts isolated from first-trimester chorionic villi. J Reprod Med 39, 249-256.

Kuijk, E.W., Du Puy, L., Van Tol, H.T.A., Oei, C.H.Y., Haagsman, H.P., Colenbrander, B., Roelen, B.A.J., 2008. Differences in early lineage segregation between mammals. Dev. Dyn. 237, 918-927. https://doi.org/10.1002/dvdy.21480

Lau, M.M., Stewart, C.E., Liu, Z., Bhatt, H., Rotwein, P., Stewart, C.L., 1994. Loss of the imprinted IGF2/cationindependent mannose 6-phosphate receptor results in fetal overgrowth and perinatal lethality. Genes Dev. 8, 2953-2963. https://doi.org/10.1101/gad.8.24.2953

Laughlin, T.D., Miles, J.R., Wright-Johnson, E.C., Rempel, L.A., Lents, C.A., Pannier, A.K., 2017. Development of preimplantation porcine blastocysts cultured within alginate hydrogel systems either supplemented with secreted phosphoprotein 1 or conjugated with Arg-Gly-Asp Peptide. Reprod. Fertil. Dev. 29, 2345-2356. https://doi.org/ $10.1071 / \mathrm{RD} 16366$

Lefèvre, F., Martinat-Botté, F., Locatelli, A., De Niu, P., Terqui, M., La Bonnardière, C., 1998. Intrauterine infusion of high doses of pig trophoblast interferons has no antiluteolytic effect in cyclic gilts. Biol. Reprod. 58, 10261031. https://doi.org/10.1095/biolreprod58.4.1026

Letcher, R., Simmen, R.C., Bazer, F.W., Simmen, F.A., 1989. Insulin-like growth factor-I expression during early conceptus development in the pig. Biol. Reprod. 41, 1143-1151. https://doi.org/10.1095/biolreprod41.6.1143

Li, H.-T., Ma, B., Mi, J.-W., Jin, H.-Y., Xu, L.-N., Wang, J.-W., 2007. Molecular cloning and functional analysis of goose interferon gamma. Vet. Immunol. Immunopathol. 117, 67-74.

https://doi.org/10.1016/j.vetimm.2007.01.009

Li, J., Dong, X.-Y., Yang, P.-W., Yang, S.-L., Hu, D., Zhang, H.-W., Sui, C., 2019. Activation of Uterine Smad3 Pathway Is Crucial for Embryo Implantation. Curr Med Sci 39, 997-1002. https://doi.org/10.1007/s11596-0192134-Z

Lin, H., Wang, X., Liu, G., Fu, J., Wang, A., 2007. Expression of alphaV and beta3 integrin subunits during implantation in pig. Mol. Reprod. Dev. 74, 1379-1385. https://doi.org/10.1002/mrd.20732

Liu, J.P., Baker, J., Perkins, A.S., Robertson, E.J., Efstratiadis, A., 1993. Mice carrying null mutations of the genes encoding insulin-like growth factor I (Igf-1) and type 1 IGF receptor (Igf1r). Cell 75, 59-72. 
Llobat, L., Marco-Jiménez, F., Peñaranda, D.S., Thieme, R., Navarrete, A., Vicente, J.S., 2012. mRNA expression in rabbit blastocyst and endometrial tissue of candidate gene involved in gestational losses. Reprod. Domest. Anim. 47, 281-287. https://doi.org/10.1111/j.1439-0531.2011.01855.x

Meng, Y., Moore, R., Tao, W., Smith, E.R., Tse, J.D., Caslini, C., Xu, X.-X., 2018. GATA6 phosphorylation by Erk1/2 propels exit from pluripotency and commitment to primitive endoderm. Dev. Biol. 436, 55-65. https://doi.org/ 10.1016/j.ydbio.2018.02.007

Murrell, A., Heeson, S., Cooper, W.N., Douglas, E., Apostolidou, S., Moore, G.E., Maher, E.R., Reik, W., 2004. An association between variants in the IGF2 gene and Beckwith-Wiedemann syndrome: interaction between genotype and epigenotype. Hum. Mol. Genet. 13, 247-255. https://doi.org/10.1093/hmg/ddh013

Muscettola, M., Massai, L., Lodi, L., Briganti, F., Fontani, G., Lupo, C., 2003. IFN-gamma production in rabbits: behavioral and endocrine correlates. Life Sci. 72, 1331-1343. https://doi.org/10.1016/s0024-3205(02)02378-0

Paria, B.C., Dey, S.K., 1990. Preimplantation embryo development in vitro: cooperative interactions among embryos and role of growth factors. Proc. Natl. Acad. Sci. U.S.A. 87, 4756-4760. https://doi.org/10.1073/pnas.87.12.4756

Pauken, C.M., Capco, D.G., 1999. Regulation of cell adhesion during embryonic compaction of mammalian embryos: roles for PKC and beta-catenin. Mol. Reprod. Dev. 54, 135-144. https://doi.org/10.1002/(SICI)10982795(199910)54:2<135::AID-MRD5>3.0.CO;2-A

Pinto, A.B., Schlein, A.L., Moley, K.H., 2002. Preimplantation exposure to high insulin-like growth factor I concentrations results in increased resorption rates in vivo. Hum. Reprod. 17, 457-462. https://doi.org/10.1093/humrep/17.2.457

Rashev, P., Georgieva, R., Rees, D., 2005. Expression of alpha5beta1 integrin and fibronectin during early pregnancy in pigs. Folia Biol. (Praha) 51, 121-125.

Rinderknecht, E., Humbel, R.E., 1978. The amino acid sequence of human insulin-like growth factor I and its structural homology with proinsulin. J. Biol. Chem. 253, 2769-2776.

Ritvos, O., Ranta, T., Jalkanen, J., Suikkari, A.M., Voutilainen, R., Bohn, H., Rutanen, E.M., 1988. Insulin-like growth factor (IGF) binding protein from human decidua inhibits the binding and biological action of IGF-I in cultured choriocarcinoma cells. Endocrinology 122, 2150-2157. https://doi.org/10.1210/endo-122-5-2150

Rogers, J., Wiltrout, L., Nanu, L., Fant, M.E., 1996. Developmentally regulated expression of IGF binding protein-3 (IGFBP-3) in human placental fibroblasts: effect of exogenous IGFBP-3 on IGF-1 action. Regul. Pept. 61, 189-195. https://doi.org/10.1016/0167-0115(95)00155-7 
Samiec, M., Romanek, J., Lipiński, D., Opiela, J., 2019. Expression of pluripotency-related genes is highly dependent on trichostatin A-assisted epigenomic modulation of porcine mesenchymal stem cells analysed for apoptosis and subsequently used for generating cloned embryos. Anim. Sci. J. https://doi.org/10.1111/asj.13260

Schrode, N., Saiz, N., Di Talia, S., Hadjantonakis, A.-K., 2014. GATA6 Levels Modulate Primitive Endoderm Cell Fate Choice and Timing in the Mouse Blastocyst. Dev Cell 29, 454-467. https://doi.org/10.1016/j.devcel.2014.04.011

Sferruzzi-Perri, A.N., Owens, J.A., Pringle, K.G., Robinson, J.S., Roberts, C.T., 2006. Maternal insulin-like growth factors-I and -II act via different pathways to promote fetal growth. Endocrinology 147, 3344-3355. https://doi.org/10.1210/en.2005-1328

Sferruzzi-Perri, A.N., Owens, J.A., Standen, P., Taylor, R.L., Robinson, J.S., Roberts, C.T., 2007. Early pregnancy maternal endocrine insulin-like growth factor I programs the placenta for increased functional capacity throughout gestation. Endocrinology 148, 4362-4370. https://doi.org/10.1210/en.2007-0411

Sharkey, A., 1998. Cytokines and implantation. Rev. Reprod. 3, 52-61.

Shen, Q.-Y., Yu, S., Zhang, Y., Zhou, Z., Zhu, Z.-S., Pan, Q., Lv, S., Niu, H.-M., Li, N., Peng, S., Liao, M.-Z., Wang, H.Y., Lei, A.-M., Miao, Y.-L., Liu, Z.-H., Hua, J.-L., 2019. Characterization of porcine extraembryonic endoderm cells. Cell Prolif. 52, e12591. https://doi.org/10.1111/cpr.12591

Smith, C., Berg, D., Beaumont, S., Standley, N.T., Wells, D.N., Pfeffer, P.L., 2007. Simultaneous gene quantitation of multiple genes in individual bovine nuclear transfer blastocysts. Reproduction 133, 231-242. https://doi.org/10.1530/rep.1.0966

Stenhouse, C., Hogg, C.O., Ashworth, C.J., 2019. Association of foetal size and sex with porcine foeto-maternal interface integrin expression. Reproduction 157, 317-328. https://doi.org/10.1530/REP-18-0520

Ullrich, A., Gray, A., Tam, A.W., Yang-Feng, T., Tsubokawa, M., Collins, C., Henzel, W., Le Bon, T., Kathuria, S., Chen, E., 1986. Insulin-like growth factor I receptor primary structure: comparison with insulin receptor suggests structural determinants that define functional specificity. EMBO J. 5, 2503-2512.

Valdés, G., Erices, R., Chacón, C., Corthorn, J., 2008. Angiogenic, hyperpermeability and vasodilator network in uteroplacental units along pregnancy in the guinea-pig (Cavia porcellus). Reprod. Biol. Endocrinol. 6, 13. https://doi.org/10.1186/1477-7827-6-13

Vejlsted, M., Offenberg, H., Thorup, F., Maddox-Hyttel, P., 2006. Confinement and clearance of OCT4 in the porcine embryo at stereomicroscopically defined stages around gastrulation. Mol. Reprod. Dev. 73, 709-718. https://doi.org/10.1002/mrd.20461 
Vélez, C., Clauzure, M., Williamson, D., Koncurat, M.A., Santa-Coloma, T.A., Barbeito, C., 2019. IL-1ß, IL-2 and IL-4 concentration during porcine gestation. Theriogenology 128, 133-139.

https://doi.org/10.1016/j.theriogenology.2019.01.017

Wang, Y., Hu, T., Wu, L., Liu, X., Xue, S., Lei, M., 2017. Identification of non-coding and coding RNAs in porcine endometrium. Genomics 109, 43-50. https://doi.org/10.1016/j.ygeno.2016.11.007

Wei, Q., Li, R., Zhong, L., Mu, H., Zhang, S., Yue, L., Xiang, J., Li, E., Zhi, M., Cao, S., Han, J., 2018. Lineage specification revealed by single-cell gene expression analysis in porcine preimplantation embryos. Biol. Reprod. 99, 283-292. https://doi.org/10.1093/biolre/ioy062

Westwood, M., Gibson, J.M., Davies, A.J., Young, R.J., White, A., 1994. The phosphorylation pattern of insulin-like growth factor-binding protein-1 in normal plasma is different from that in amniotic fluid and changes during pregnancy. J. Clin. Endocrinol. Metab. 79, 1735-1741. https://doi.org/10.1210/jcem.79.6.7527409

Whyte, J.J., Meyer, A.E., Spate, L.D., Benne, J.A., Cecil, R., Samuel, M.S., Murphy, C.N., Prather, R.S., Geisert, R.D., 2018. Inactivation of porcine interleukin-1 $\beta$ results in failure of rapid conceptus elongation. Proc. Natl. Acad. Sci. U.S.A. 115, 307-312. https://doi.org/10.1073/pnas.1718004115

Wildman, D.E., Chen, C., Erez, O., Grossman, L.I., Goodman, M., Romero, R., 2006. Evolution of the mammalian placenta revealed by phylogenetic analysis. Proc. Natl. Acad. Sci. U.S.A. 103, 3203-3208. https://doi.org/10.1073/pnas.0511344103

Wilson, D.M., Bennett, A., Adamson, G.D., Nagashima, R.J., Liu, F., DeNatale, M.L., Hintz, R.L., Rosenfeld, R.G., 1982. Somatomedins in pregnancy: a cross-sectional study of insulin-like growth factors I and II and somatomedin peptide content in normal human pregnancies. J. Clin. Endocrinol. Metab. 55, 858-861. https://doi.org/10.1210/jcem-55-5-858

Wolf, X.A., Serup, P., Hyttel, P., 2011. Three-dimensional immunohistochemical characterization of lineage commitment by localization of T and FOXA2 in porcine peri-implantation embryos. Dev. Dyn. 240, 890-897. https://doi.org/10.1002/dvdy.22602

Yoon, J.D., Hwang, S.-U., Kim, M., Lee, G., Jeon, Y., Hyun, S.-H., 2019. GDF8 enhances SOX2 expression and blastocyst total cell number in porcine IVF embryo development. Theriogenology 129, 70-76. https://doi.org/10.1016/j.theriogenology.2019.02.007

Złotkowska, A., Andronowska, A., 2019. Chemokines as the modulators of endometrial epithelial cells remodelling. Sci Rep 9, 12968. https://doi.org/10.1038/s41598-019-49502-5 
201

202 